UDC 342.9

DOI https://doi.org/10.32849/2663-5313/2021.9.10

Sergey Petkov,

Doctor of Law, Professor, Professor at the Department of Military Law, Military Institute of Taras Shevchenko National University of Kyiv, 81, Mykhailo Lomonosov street, Kyiv, Ukraine, postal code 03680,svpetkov@ukr.net

ORCID: orcid.org/0000-0003-4160-767X

Igor Ivanov,

PhD in Law, PhD in Engineering, Honoured Worker of Transport of Ukraine, Chairman, Zaporozhoblavtotrans Association, 30, Pokrovska street, Zaporizhzhia, Ukraine, postal code 69063, ieivanow@gmail.com

ORCID: orcid.org/0000-0002-9650-1293

Petkov, Sergey, Ivanov, Igor (2021). Establishment and development of information and legal support of the National Police of Ukraine. Entrepreneurship, Economy and Law, 9, 66-73, doi: https://doi.org/10.32849/2663-5313/2021.9.10

\title{
ESTABLISHMENT AND DEVELOPMENT OF INFORMATION AND LEGAL SUPPORT OF THE NATIONAL POLICE OF UKRAINE
}

Abstract. Purpose. The aim of the article is a retrospective analysis of the information and legal support of law enforcement bodies. Results. The article is a retrospective analysis of information and legal support of the National Police of Ukraine. It is proven that the development of information support for activities of law enforcement bodies are interrelated with the evolutionary stages of information technology development. Six stages in the development of information support for law enforcement bodies are identified and analysed. The study reveals that: for the first time, the Ministry of Internal Affairs introduced the Instruction on keeping records in internal affairs bodies in 1961, and specifically the formation of the scientific and practical basis for information support of the law enforcement bodies of Ukraine began in the early 1970s; at that time, the Republican Research Information Centre of the Ministry of Internal Affairs of the Ukrainian SSR (now the Department of Information and Analytical Support of the National Police of Ukraine) was launched with its data processing centres in all regional Internal Affairs Directorates that were equipped with Minsk-type computers and later with EU media. It is revealed that the specificity of making information systems at that time was that information was not processed centrally, which had affected and sometimes made it impossible for law enforcement officers to have direct access to a unified database. Conclusions. The police's competence with regard to the information, information and analytical support, making and application of information resources are set out in article 25 of the Law of Ukraine "On National Police." The legal regulations governing activities in this area are analysed. It is theoretically justified that a positive novelty in the legal regulatory mechanism for information support to police activities is the legislative consolidation of the police's information and analytical activities, their powers in this field, the list of databases, as well as liability for misuse of information resources. It is established that the use of information technology in the performance of the National Police, with appropriate legal support, may become one of the main factors in strengthening the rule of law in our country.

Key words: stages of development, information support, legal support, information portal, integrated information network.

\section{Introduction}

The establishment of a legal basis for information support of activities of the National Police is historically inextricably linked to the establishment and development of their institutional and functional system. The active development of information processes and the introduction of new inventions, achievements and technol- ogies into production and management processes have driven not only the progressive development of our State but have also contributed to the increase in the number of crimes and the improvement of the means and methods of committing them. Therefore, the development of qualitative parameters for information support to the National Police of Ukraine 
and the legal basis for its use are increasingly relevant. It allows finding new ways of crime prevention, promoting effective and accurate decision-making for the detection of crimes that has been already well understood at its level in ancient times.

The development of information systems in the activities of the National Police of Ukraine in current circumstances is rapidly improving, but issues of the day occur, since now the information systems and their legal support cannot fully realize their objective.

The problem of information and legal support of the activities of law enforcement bodies has been studied in the historical context in the works by S. Banakh, A. Volodko, R. Kaliuzhnyi, M. Kryshtanovych, I. Katerynchuk, M. Perepelytsia, T. Tankushyn, V. Tkachenko, I. Khort, A. Frolov, A. Yankovska. However, the dynamics of the information society development in general, as well as the ongoing reform of the National Police of Ukraine, demonstrate the relevance of this issue.

The aim of the article is a retrospective analysis of the information and legal support of activities of law enforcement bodies.

2. The role of information support of law enforcement agencies

In modern conditions, the legal basis for information support of the activities of the National Police of Ukraine opens up new possibilities for crime prevention, promotes effective and accurate decision-making for crime detection, including in "hot pursuit."

According to legal scholars, the development of information support in law enforcement is important. For example, A. Frolova argues that in many cases the priority of information support in the process of effective administration in the internal affairs bodies and functioning of the entire law enforcement system is confirmed by the practice of combating crime. The important role of the information system in law enforcement bodies has been approved at the legislative level, in particular by Orders of the Ministry of Internal Affairs of Ukraine (Frolova, 2002, p. 55).

According to I. Katerinchuk, the study of the genesis of information support of law enforcement bodies, including the legal basis for their use, reveals a link between the development of information support to law enforcement activities and the evolutionary stages of information technology. The scientist identifies six stages in the development of information support to law enforcement bodies. In the first stage, human speech emerges, which greatly facilitates the exchange of information in personal contact, as well as the accumulation of information resources, the presence of persons responsible for their storage. In the second stage of evolution, writing emerged, and the first printing press in 1445 marked the beginning of the third stage of information technology development that lasted about 500 years, an important achievement of which was the emergence of information support to law enforcement bodies depending on their activities. During the fourth period (the late XIX - the beginning of the XX century) of the information evolution means of communication were invented and spread: radio, telegraph, telephone, etc. In 1907, a number of legal regulations were adopted and contributed to the improvement of information and analytical work of the police, in particular "Regulation on security departments," "Instruction on organization and conduct of internal (undercover) surveillance" (Katerynchuk, 2015). At this period, the first theoretical works on judicial recordkeeping and registration occur. For example, the famous criminologist V. Lebedev published the book Art of crime detection, which contained detailed scientific information on fingerprinting, anthropometry and forensic photography of the police. In 1915, S. Trebugov published a practical guide for forensic investigators, The basics of criminal technology: Scientific and technical methods of crime investigation, revealing information related to crime registration (Tregubov, 2002). With the advent of the first electronic computing machines (computers) in 1946, the fifth evolution stage of information technology began, and in the sixth stage up to this day, a microprocessor and a personal computer were invented (Banakh, 2019, p. 12).

It should be noted that in 1917-1921, law enforcement bodies, such as the Gendarmerie, the Hetmanschyna Guard, the People's Militia Directorate, the Intelligence and Counterintelligence Service, the Office of the Procurator, the Security Service and other special services, responsible for combatting crime, the law and order, as well as lawful conduct in the State, were established in the territory of modern Ukraine. In addition to undercover method, external surveillance and other operational practices, information analysis was also widely applied.

Until 1960, Ukraine did not have a unified system of registration in law enforcement bodies; only in 1961 the Ministry of Internal Affairs introduced an Instruction on keeping records in internal affairs bodies. The establishment of the scientific and practical basis for information support to the law enforcement bodies of Ukraine began in the early 1970s. At that time, the Republican Research Information Centre (RRIC) of the Ministry of Internal Affairs of the Ukrainian SSR (now the Depart- 
ment of Information and Analytical Support of the National Police of Ukraine) was launched with its data processing centres in all regional Internal Affairs Directorates that were equipped with Minsk-type computers and later with EU media. The information centres have become centres for the collection of basic information and technical tools for the data-processing, functional automated information systems that have had their specific objective, tasks, level of operation and so on. According to R. Kaliuzhnyi and V. Tkachenko, at that time the automated information systems used in law enforcement did not differ significantly from those used in other branches of the national economy (Kaliuzhnyi, \& Tkachenko, 1991, p. 65). The specificity of making information systems at that time was that information was not processed centrally, which had affected and sometimes made it impossible for law enforcement officers to have direct access to a unified database.

The establishment of a unified database containing all the necessary information for the performance of law enforcement functions was impeded by the following factors: first, the lack of technical capacity of the information centres of the Soviet law enforcement system; second, underutilization of the latest programming resources of the time. The purpose of using information and analytical support to bodies was statistical analysis of information, criminal records and monitoring of consideration of reports and allegations of crimes and offences (Kryshtanovych, 2012).

3. Formation of information and legal support for the activities of the National Police of Ukraine

At the beginning of 1980, the government of the USSR developed and adopted the Strategy "Automation of information support to management activities," which was based on the idea of creation of an automated workplace (AWP) for the employee of internal affairs bodies. This Strategy determined the development of a complex for automating the intellectual work of an individual employee and transmitting information "from bottom to top" and "from the periphery to the centre" (Tankushyna, 2011). In 1985, a unified automated databank was established, which concentrated the information required by law enforcement to perform their functions. Automated operational information systems were installed in all duty units of the internal affairs bodies. The system contained a suite of software, information, organizational and technical tools used to collect and store information, as well as to monitor and report at duty stations. In 1988, the Department of Technical Means of Crime Prevention and Detection was established, which was later reorganized into the Information Technology Department of the National Academy of Internal Affairs of Ukraine.

Undoubtedly, the improvement of the system of information support to internal affairs bodies has contributed to increase in crime prevention and control in the country. The persuasive factor was that electronic computing machines had enabled law enforcement officers to automate routine and labour-intensive work and to use them to enhance their ability to perform the relevant duties. The use of the computer has enabled law enforcement officers to identify trends and patterns in the fight against crime and the enforcement of public order (Khort, 2015).

The focus should be on all available assistance in the use of the latest information-processing tools in the field of investigative and reference work. In particular, such automated information systems (AIS) as: "Administrative practice," "Prophylaxis-Search," "Delivered," "Numbered things," "Person," "Patrols," "Legal regulations" and others have already proved their effectiveness at the first stage of their implementation. For example, in the few months of operation AIS "Prophylaxis-Search" contributed to a $16 \%$ reduction in the number of crimes committed by persons previously convicted in the capital, and thanks to AIS "Statistics" the number of unreliable indicators on solving crimes decreased. At that time, the computer was also used to combat economic crime and a number of methods and tools were introduced for retrospective analysis of the activities of organizations in various sectors of the economy. In the nineties of the last century the sectoral information system "Legal regulations" was launched and later transformed into information systems "Law," "Legislation," "Legal regulations of Ukraine."

In 1991, the Ministry of Internal Affairs began to set up the first local computer network, to which the heads of the Ministry of Internal Affairs and the leading services of the structural departments of law enforcement bodies were given access. Undeniably, in 1992, the publication of the main legal regulation on information relations in Ukraine, the Law of Ukraine "On Information" (Law of Ukraine On Information, 1992) was the beginning of the formation of the unified system of data processing of the Ministry of Internal Affairs, where information was processed in a unified way, based on common inputs and reference materials for different tasks.

In 1998, the Ukrainian internal affairs bodies introduced a computer system for information collection and dissemination by electronic mail, which contributed to better 
reporting prompt information on the commission of offences and other high-profile events to the heads of regional departments and the staff of the Ministry of Internal Affairs.

In 2000, the information network consisted of local computer networks of structural units of the Ministry of Internal Affairs of Ukraine and its regional units, which were merged into the unified information system. The local networks of each structural unit operated independently and autonomously. The relevant structural unit of the Ministry of the Internal Affairs established and maintained loca computerized databases, which were accessed according to the official needs of the employees (Perepelytsia, Volodko, 2016; Kryshtanovych, 2016).

In 2002, the Ministry of Internal Affairs established the Department of Information and Analytical Support (DIAS), responsible, inter alia, for the development and introduction of information technologies in the performance of the internal affairs bodies of Ukraine (Iankovska, 2010, p. 80). In addition, the DIAS provided such electronic data as "Missing citizens," "Persons hiding from authorities," "Unidentified corpses," "Cultural values," "Mobile phones," "Wanted vehicles," "Wanted firearms" etc.

In 2006, on the basis of the DIAS the Ministry of Internal Affairs considered the establishment of an operational and analytical unit, responsible for the development of operational and analytical structures in the central bodies and regional police units, however, the objective and clear duties were not defined. In this connection, in 2007 the Ministry of Internal Affairs created instead a Department of Strategic Analysis and Estimating and the Information Technology Sectors (ITS) within city, district and line internal affairs bodies (Kryshtanovych, 2012).

It should be noted that the further increase in the crime rate in Ukraine has motivated the improvement of existing and the development of new approaches in the work of internal affairs bodies. One of the priority tasks of information support was to establish a unified integrated information network in the MIA of Ukraine, which would contain all previously recorded and new information for the purposes of operational searches. In order to solve this problem, a suite of software of the information and search system "AWPOO" (automated working place of the operative officer), developed in 2003 by the Directorate of the MIA of the Luhansk region, was taken as a basis, and in 2009, on the grounds of the Regulations on the Integrated Information and Search System of the Internal Affairs Bodies of Ukraine, it was introduced as a reference system in all regional units of the MIA.

The Integrated Information Search System (IISS) is a set of organizational, administrative, software and information and telecommunications tools for the processing of reference and information, operational and search records and provides authorized user with access to information resources of the IISS. This provision clearly defines the objectives of the operation of the IISS: to integrate information resources existing in internal affairs bodies and units into a unified information and analytical complex through the use of the latest information technologies, computer and telecommunication equipment to support the operational and official duties of internal affairs bodies and units and to enhance their effectiveness to counter and prevent crime (Order of the Ministry of Internal Affairs of Ukraine On approval of the Regulations on the Integrated Information Search System of the Bodies of Internal Affairs of Ukraine, 2009).

In accordance with the Regulations on the Integrated Information and Search System of the Internal Affairs Bodies of Ukraine, the Algorithm for user action on making IIPS was developed for use in the performance of official duties in the field of law enforcement. At the same time, regional and central IIPS information records are available only to authorized IIPS users. Currently, the IIPS involves 19 computer information subsystems (AIS "Person," AIS "Fingerprint accounting," AIS "Unsolved crimes," AIS "Orion," etc.).

Undeniably, the Law of Ukraine "On the National Police" (Law of Ukraine On the National Police, 2015) is an important and leading regulatory instrument of information support to the police, since it empowers the police to use information and analytical support, to establish and use information resources. In other words, it can be interpreted as a positive novelty in the legal and regulatory framework for this sector as compared to the previous state of the legal regulatory mechanism is the legislative consolidation of the information analysis by the police, their powers in this field, the list of databases, as well as liability for misuse of information resources.

4. The current state of information and legal support of the National Police of Ukraine

In order to increase effectiveness in this area of service, at the end of 2015, the Department of Information Support and Coordination of Police Activities '102' (DISCP) was established in the National Police of Ukraine to take measures under Ukrainian legislation aimed at information and analytical, information 
and search support to law enforcement activities and protection of personal data during processing in the structural units of the National Police of Ukraine. The DISCP was later reorganized as a Department of Information and Analytical Support (DIAS), focused on: information and search, analytical support; participation in drafting of legislation of the Ministry of Internal Affairs on matters within the competence of the police and related to information and analytical support, as well as processing of personal data in police bodies and units.

In the context of law enforcement reform, the legal and regulatory framework for using opportunities of information support to the National Police of Ukraine and the Ministry of Internal Affairs of Ukraine during the prevention of crime and the detection of crimes, including in "hot pursuit," has been improved. For example, in 2016, the Ministry of Internal Affairs of Ukraine, with a view to determining the procedure for the operation of the Unified Digital Departmental Telecommunication Network of the MIA and the rules for cooperation between the Ministry of Internal Affairs, the National Guard and the central executive authorities, guided and coordinated by the Minister of Internal Affairs of Ukraine, with regard to access to the resources and services of the Unified Digital Departmental Telecommunication Network of the Ministry of Internal Affairs, the relevant regulations were adopted (Order of the Ministry of Internal Affairs of Ukraine On the Regulations on the Unified Digital Departmental Telecommunication Network of the Ministry of Internal Affairs, 2016; Order of the Ministry of Internal Affairs of Ukraine On approval of the Instruction on the procedure for mutual use of video surveillance systems of the Security Service of Ukraine, the Department of State Protection of Ukraine, the Ministry of Internal Affairs of Ukraine and the National Police of Ukraine, 2016).

In 2017-2020, the MIA of Ukraine issued a number of other legal regulations in this area of service activities, namely on the functioning of the integrated information and search system "Information portal of the National Police of Ukraine" (IPNP) (Order of the Ministry of Internal Affairs of Ukraine On approval of the Regulations on the automated information system for the operational purpose of the unified information system of the Ministry of Internal Affairs, 2017), establishment and maintenance of information subsystems "Harpoon" (Order of the Ministry of Internal Affairs of Ukraine on approval of the Instruction on formation of the information subsystem "Harpoon" of the information and telecommunication system "Information portal of the National Police of Ukraine", 2018), "Unified Accounting" (Order of the Ministry of Internal Affairs of Ukraine On approval of the Instruction on formation and maintenance of the information subsystem "Unified Accounting" of the information and telecommunication system "Information Portal of the National Police of Ukraine", 2019), "Road accident" (Order of the Ministry of Internal Affairs of Ukraine On approval Instruction on formation and maintenance of the information subsystem "Road accident" of the information and telecommunication system "Information portal of the National Police of Ukraine", 2020) and others.

Similarly, the National Police, which is part of the Ministry of Internal Affairs, work to improve the legal basis for the use of information. In particular, the Regulation on the Internet system in the telecommunication network of the National Police of Ukraine was approved in 2017 (Order of the Ministry of Internal Affairs of Ukraine On approval Regulations on the Internet system in the telecommunication network of the National Police of Ukraine, 2017); and in the following year, regulations provided for the monitoring of the use of SIM cards for mobile communication devices used to work with NPU information resources (Order of the National Police of Ukraine On Approval of the Procedure for Control over the Use of SIM Cards for Mobile Communication Devices Used to Work with Information Resources of the National Police of Ukraine, 2018).

\section{Conclusions}

To sum up, the development of the informatization of the State law enforcement system in Ukraine has been consistent with European and global trends. It began in the 18th and 19th centuries and peaked in the 20th and 21st centuries. Nowadays, relations in the field of information support of the activities of the National Police are still being regulated at the legislative level, since new approaches are constantly being developed to ensure the information security of existing information systems in the NPU and the MIA of Ukraine. Furthermore, new information and analysis products are introduced in the work of the various units of NPU and the range of actors able to use them are broadened. The use of information technologies in the performance of the National Police, with appropriate legal support, may become one of the main factors in strengthening the rule of law in our country. 


\section{References:}

Banakh, S. (2019). Informatsiine zabezpechennia diialnosti pravookhoronnykh orhaniv: istoryko-pravovyi analiz [Information support to law enforcement bodies: historical and legal analysis]. Aktualni problemy pravoznavstva - Actual problems of jurisprudence, 2(18), 149-156 (in Ukrainian).

Frolova, O.H. (2002). Problemy pravovoho rehuliuvannia informatsiino-metodychnoho upravlinnia v orhanakh vnutrishnikh sprav [Problems of legal regulation of information and methodical management in law-enforcement bodies]. Problemy pravoznavstva ta pravookhoronnoi diialnosti Problems of jurisprudence and law enforcement, 1, 53-62 (in Ukrainian).

Iankovska, O.H. (2010). Do pytannia efektyvnosti systemy informatsiinoho zabezpechennia u rozkrytti ta rozsliduvanni zlochyniv [On the effectiveness of information support system in the detection and investigation of crimes]. Pravova informatyka - Legal informatics, 2, 78-81 (in Ukrainian).

Kaliuzhnyi, R., \& Tkachenko, V. (1991). Avtomatyzovani informatsiini systemy i osoblyvosti yikh vykorystannia $\mathrm{v}$ orhanakh vnutrishnikh sprav [Automated information systems and features of their use in law enforcement bodies]. Yedynyi pravnychyi zhurnal «Radianske pravo» - Unified Law Journal "Soviet Law", 3, 65-68 (in Ukrainian).

Katerynchuk, I.P. (2015). Pravovi zasady informatsiinoho zabezpechennia diialnosti pravookhoronnykh orhaniv Ukrainy [Legal bases of information support to activity of law enforcement bodies of Ukraine]. Extended abstract of Doctor's thesis. Kyiv (in Ukrainian).

Khort, I.V. (2015). Osoblyvosti informatsiinoho zabezpechennia orhaniv vnutrishnikh sprav u sferi okhoronnoi diialnosti [Features of Information support to law enforcement bodies in the field of security activities]. Naukovi pratsi MAUP - Scientific works of IAPM, 44(1), 100-107 (in Ukrainian).

Kryshtanovych, M.F. (2012). Derzhavne upravlinnia informatsiino-analitychnym zabezpechenniam diialnosti orhaniv vnutrishnikh sprav Ukrainy: stan ta perspektyvy rozvytku [State management of information and analytical support to the internal affairs bodies of Ukraine: state and prospects of development]. Teoriia ta praktyka derzhavnoho upravlinnia - Theory and practice of public administration, 4, 104-111 (in Ukrainian).

Kryshtanovych, M.F. (2016). Modernizatsiia mekhanizmiv derzhavnoho upravlinnia v systemi orhaniv vnutrishnikh sprav suchasnoi Ukrainy [Modernization of public administration mechanisms in the system of internal affairs bodies of modern Ukraine]. Doctor's thesis. Chornomor. nats. un-t im. Petra Mohyly. Mykolaiv (in Ukrainian).

Nakaz Ministerstva vnutrishnikh sprav Ukrainy Pro Polozhennia pro yedynu tsyfrovu vidomchu telekomunikatsiinu merezhu MVS : pryiniatyi 4 lyp. 2016 № 596 [Order of the Ministry of Internal Affairs of Ukraine On the Regulations on the Unified Digital Departmental Telecommunication Network of the Ministry of Internal Affairs of July 2016 № 596]. (2016). zakon.rada.gov.ua. Retrieved from https://zakon.rada.gov.ua/laws/show/z1055-16\#Text (in Ukrainian).

Nakaz Ministerstva vnutrishnikh sprav Ukrainy Pro zatverdzhennia Polozhennia pro Intehrovanu informatsiino-poshukovu systemu orhaniv vnutrishnikh sprav Ukrainy : pryiniatyi 12 veres. 2009 № 436 [Order of the Ministry of Internal Affairs of Ukraine On approval of the Regulations on the Integrated Information Search System of the Bodies of Internal Affairs of Ukraine of September 122009 № 436]. (2009). zakon.rada.gov.ua. Retrieved from https://zakon.rada.gov.ua/ laws/show/z1256-09.\#Text (in Ukrainian).

Nakaz Ministerstva vnutrishnikh sprav Ukrainy Pro zatverdzhennia Instruktsii pro poriadok vzaiemnoho vykorystannia system videosposterezhennia Sluzhby bezpeky Ukrainy, Upravlinnia derzhavnoi okhorony Ukrainy, Ministerstva vnutrishnikh sprav Ukrainy ta Natsionalnoi politsii Ukrainy : pryiniatyi 12 veres. 2016 № 917 [Order of the Ministry of Internal Affairs of Ukraine On approval of the Instruction on the procedure for mutual use of video surveillance systems of the Security Service of Ukraine, the Department of State Protection of Ukraine, the Ministry of Internal Affairs of Ukraine and the National Police of Ukraine of September 122016 № 917]. (2016). zakon. rada.gov.ua. Retrieved from https://zakon.rada.gov.ua/laws/show/z1292-16\#Text (in Ukrainian).

Nakaz Ministerstva vnutrishnikh sprav Ukrainy Pro zatverdzhennia Polozhennia pro avtomatyzovanu informatsiinu systemu operatyvnoho pryznachennia yedynoi informatsiinoi systemy MVS : pryiniatyi 20 zhovt. 2017 № 870 [Order of the Ministry of Internal Affairs of Ukraine On approval of the Regulations on the automated information system for the operational purpose of the unified information system of the Ministry of Internal Affairs of October 20 2017 № 870]. (2017). zakon.rada.gov.ua. Retrieved from https://zakon.rada.gov.ua/laws/show/ z1433-17\#Text (in Ukrainian).

Nakaz Ministerstva vnutrishnikh sprav Ukrainy Pro zatverdzhennia Instruktsii z formuvannia ta vedennia informatsiinoi pidsystemy «Iedynyi oblik» informatsiino-telekomunikatsiinoi 
systemy «Informatsiinyi portal Natsionalnoi politsii Ukrainy» : pryiniatyi 14 cherv. 2019 № 508 [Order of the Ministry of Internal Affairs of Ukraine On approval of the Instruction on formation and maintenance of the information subsystem "Unified Accounting" of the information and telecommunication system "Information Portal of the National Police of Ukraine" of June 142019$].$ (2019).zakon.rada.gov.ua. Retrieved from https://zakon.rada.gov.ua/laws/show/z0739-19\#Text (in Ukrainian)

Nakaz Ministerstva vnutrishnikh sprav Ukrainy Pro zatverdzhennia Instruktsii z formuvannia ta vedennia informatsiinoi pidsystemy «Dorozhno-transportna pryhoda» informatsiino-telekomunikatsiinoi systemy «Informatsiinyi portal Natsionalnoi politsii Ukrainy» : pryiniatyi 15 lyp. 2020 № 533 [Order of the Ministry of Internal Affairs of Ukraine On approval Instruction on formation and maintenance of the information subsystem "Road accident" of the information and telecommunication system "Information portal of the National Police of Ukraine" of July 15 2020 № 533]. (2020). zakon.rada.gov.ua. Retrieved from https://zakon.rada.gov.ua/laws/show/ z0726-20\#Text (in Ukrainian).

Nakaz Ministerstva vnutrishnikh sprav Ukrainy Pro zatverdzhennia Polozhennia pro systemu Internet u telekomunikatsiinii merezhi Natsionalnoi politsii Ukrainy : pryiniatyi 21 liut. 2017 № 141 [Order of the Ministry of Internal Affairs of Ukraine On approval Regulations on the Internet system in the telecommunication network of the National Police of Ukraine of February 212017 № 141]. (2017). zakon.rada.gov.ua. Retrieved from https://zakon.rada.gov.ua/laws/show/ z1059-17\#Text (in Ukrainian).

Nakaz MVS Ukrainy pro zatverdzhennia Instruktsii z formuvannia informatsiinoi pidsystemy «Harpun» informatsiino-telekomunikatsiinoi systemy «Informatsiinyi portal Natsionalnoi politsii Ukrainy» : pryiniatyi 13 cherv. 2018 № 497 [Order of the Ministry of Internal Affairs of Ukraine on approval of the Instruction on formation of the information subsystem "Harpoon" of the information and telecommunication system "Information portal of the National Police of Ukraine" June 132018 № 497]. (2018). zakon.rada.gov.ua. Retrieved from https://zakon.rada.gov.ua/laws/show/ z0787-18\#Text (in Ukrainian).

Nakaz Natsionalnoi politsii Ukrainy Pro zatverdzhennia Poriadku kontroliu za vykorystanniam SIM-kartok dlia prystroiv rukhomoho (mobilnoho) zviazku, yaki vykorystovuiutsia dlia roboty $\mathrm{z}$ informatsiinymy resursamy Natsionalnoi politsii Ukrainy : pryiniatyi $14 \mathrm{berez} .2018$ № 244 [Order of the National Police of Ukraine On Approval of the Procedure for Control over the Use of SIM Cards for Mobile (Mobile) Communication Devices Used to Work with Information Resources of the National Police of Ukraine of March 142018 № 244]. (2018). zakon.rada.goz.ua. Retrieved from https://bit.ly/3qK5bWH (in Ukrainian).

Perepelytsia, M.M., Volodko, A.H. (2016). Poriadok formuvannia informatsiinykh poshukovykh system u systemi MVS [The order of formation of information search systems in the system of the Ministry of Internal Affairs]. Visnyk Kharkivskoho natsionalnoho universytetu vnutrishnikh sprav - Bulletin of Kharkiv National University of Internal Affairs, 2, 75-85 (in Ukrainian).

Tankushyna, T.Iu. (2011). Avtomatyzovani informatsiini systemy v strukturi reiestratsiinoi diialnosti militsii: stanovlennia, rozvytok, suchasnist [Automated information systems in the structure of police registration activity: formation, development, modernity]. Visnyk Zaporizkoho natsionalnoho universytetu - Bulletin of Zaporizhia National University, 2, 201-106 (in Ukrainian).

Tregubov, S.N. (2002). Osnovy ugolovnoi tekhniki: nauchno-tekhnicheskie priemy rassledovaniia prestuplenii [Fundamentals of Criminal Technology: Scientific and Technological Methods of Crime Investigation]. Moskva: LeksEst, (in Russian).

Zakon Ukrainy Pro informatsiiu : pryiniatyi 2 zhovt. 1992 № 2567-XII [Law of Ukraine On Information of October 21992 № 2567-XII]. (1992). zakon.rada.gov.ua. Retrieved from https:// bit.ly/3AqTYyH (in Ukrainian).

Zakon Ukrainy Pro Natsionalnu politsiiu : pryiniatyi 2 lyp. 2015 № 580-VIII [ Law of Ukraine On the National Police of July 22015 № 580-VIII]. (2015). zakon.rada.gov.ua. Retrieved from https://zakon.rada.gov.ua/laws/show/580-19\#Text (in Ukrainian). 


\section{Сергій Пєтков,}

доктор юридичних наук, професор, професор кафедри військового права, Військовий інститут Київського національного університету імені Тараса Шевченка, вулиия Михайла Ломоносова, 81, Київ, Україна, індекс 03680, sopetkov@ukr.net

ORCID: orcid.org/0000-0003-4160-767X

\section{Ігор Іванов,}

кандидат юридичних наук, кандидат технічних наук, заслужений працівник транспорту України, голова, Асочіація «Запорожоблавтотранс», вулиця Покровська, 30, Запоріжжя, Україна, індекс 69063, іеілапот@gтаil.com

ORCID: orcid.org/0000-0002-9650-1293

\section{СТАНОВЛЕННЯ ТА РОЗВИТОК ІНФОРМАЦІЙНО-ПРАВОВОГО ЗАБЕЗПЕЧЕННЯ НАЦІОНАЛЬНОЇ ПОЛІЦІЇ УКРАЇНИ}

Анотація. Метою статті є ретроспективний аналіз інформаційно-правового забезпечення діяльності вітчизняних правоохоронних органів, зокрема Національної поліції України. Результати. Доведено, що розвиток інформаційного забезпечення діяльності правоохоронних органів пов’язаний з еволюційними етапами розвитку інформаційних технологій. Визначено та проаналізовано шість етапів розвитку інформаційного забезпечення правоохоронних органів. Встановлено, що вперше у правоохоронних органах запроваджено Інструкцію з діловодства в системі Міністерства внутрішніх справ України в 1961 р., натомість сам процес формування науково-практичної основи інформаційного забезпечення діяльності правоохоронних органів України розпочато на початку 1970-х рр. Тоді ж було створено Республіканський науково-дослідний інформаційний центр МВС УРСР (нині Департамент інформаційно-аналітичної підтримки Національної поліції України) із центрами обробки даних в усіх обласних управліннях внутрішніх справ. Виявлено, що специфіка створення інформаційних систем того часу полягала в тому, що інформація не оброблялася централізовано, що впливало на прямий доступ правоохоронців до єдиної бази даних, а іноді й унеможливлювало його. Висновки. Повноваження поліції щодо інформаційного, інформаційно-аналітичного забезпечення, створення й застосування інформаційних ресурсів визначені у статті 25 Закону України «Про Національну поліцію». Проаналізовано правові норми, що регулюють діяльність у цій сфері. Теоретично обгрунтовано, що позитивним нововведенням у нормативно-правовому механізмі інформаційного забезпечення діяльності поліції є законодавче закріплення інформаційно-аналітичної діяльності поліції, їі повноважень у цій сфері, переліку баз даних, а також відповідальності за неправомірне використання інформаційних ресурсів. Встановлено, що використання інформаційних технологій у діяльності Національної поліції України за належного правового забезпечення може стати одним із головних чинників зміцнення законності в нашій державі.

Ключові слова: етапи розвитку, інформаційне забезпечення, правове забезпечення, інформаційний портал, інтегрована інформаційна мережа. 